\title{
Digitalization of Public Services in Countering Criminal Corruption Offenses
}

\author{
MYKOLA STEFANCHUK ${ }^{1}$, VADYM POLYVODA ${ }^{2}$, MARIIA KIKALISHVILI ${ }^{3}$, OLESIA BODUNOVA ${ }^{4}$, \\ LILIIA YERMOLENKO-KNIAZIEVA ${ }^{5}$ \\ ${ }^{1}$ Parliament member, Honoured lawyer of Ukraine, Kyiv, Ukraine, E-mail: stefanchuk@gmail.com \\ ${ }^{2}$ Department of operational investigative activities, National Academy of Internal Affairs, Kyiv, Ukraine, \\ E-mail:vadpolyvoda@gmail.com
}

${ }^{3}$ Department of criminal law policy and criminal law, Institute of Law, Taras Shevchenko National University of Kyiv, Kyiv, E-mail: balambon9@gmail.com

${ }^{4}$ Department of Criminal Law and Criminology, University of the State Fiscal Service of Ukraine, Irpin, Ukraine, E-mail: olesalasuk@gmail.com

${ }^{5}$ Department of right and legal adjusting of aviation activity, Flying Academy of the National Aviation University, Kyiv, Ukraine, E-mail: mama25051970@ukr.net

\begin{abstract}
The article considers the main aspects of the introduction of digitalization of public services and their role in combating criminal corruption offenses. The article considers the main aspects of the introduction of digitalization of public services and their role in the fight against criminal corruption offenses. The purpose of the study is to analyze and evaluate the role of digitalization of public services in the fight against criminal corruption offenses. The current problem is political corruption at the highest level and corruption in the business environment of Ukraine. The study focuses on the challenges that have accompanied a number of reforms, including the reform of the legal system. Currently, one of the biggest reforms is the reform judicial system and constitutional proceedings. This is primarily due to people's distrust of the court. It has proved that the ability of society to overcome the phenomenon of corruption in the public sector has largely related to the willingness to transparency and openness of all information, anti-corruption maturity of both civil society and government. It is established that the fight against criminal corruption offenses, based on the tools and means of digitalization of public services, promotes public confidence in the government, becomes the basis for the formation of anticorruption culture.
\end{abstract}

Keywords: Digitalization; Public services; Criminal corruption offenses; Reforms; Digital tools.

JEL classification: K14, M15, 038

Received: April 09, 2021

Accepted: June 12, 2021 


\title{
La Digitalización de los Servicios Públicos en la Lucha contra los Delitos de Corrupción
}

\author{
MYKOLA STEFANCHUK ${ }^{1}$, VADYM POLYVODA ${ }^{2}$, MARIIA KIKALISHVILI ${ }^{3}$, OLESIA BODUNOVA ${ }^{4}$, \\ LILIIA YERMOLENKO-KNIAZIEVA ${ }^{5}$ \\ ${ }^{1}$ Parliament member, Honoured lawyer of Ukraine, Kyiv, Ukraine, E-mail: stefanchuk@gmail.com \\ ${ }^{2}$ Department of operational investigative activities, National Academy of Internal Affairs, Kyiv, Ukraine, \\ E-mail:vadpolyvoda@gmail.com \\ ${ }^{3}$ Department of criminal law policy and criminal law, Institute of Law, Taras Shevchenko National University of \\ Kyiv, Kyiv, E-mail: balambon9@gmail.com \\ ${ }^{4}$ Department of Criminal Law and Criminology, University of the State Fiscal Service of Ukraine, Irpin, Ukraine, \\ E-mail: olesalasuk@gmail.com \\ ${ }^{5}$ Department of right and legal adjusting of aviation activity, Flying Academy of the National Aviation University, \\ Kyiv, Ukraine, E-mail: mama25051970@ukr.net
}

\begin{abstract}
RESUMEN
El artículo considera los principales aspectos de la introducción de la digitalización de los servicios públicos y su papel en la lucha contra los delitos de corrupción. El artículo considera los principales aspectos de la introducción de la digitalización de los servicios públicos y su papel en la lucha contra los delitos de corrupción criminal. El propósito del estudio es analizar y evaluar el papel de la digitalización de los servicios públicos en la lucha contra los delitos de corrupción criminal. El problema actual es la corrupción política al más alto nivel y la corrupción en el entorno empresarial de Ucrania. El estudio se centra en los retos que han acompañado a una serie de reformas, incluida la reforma del sistema jurídico. Actualmente, una de las mayores reformas es la del sistema judicial y los procedimientos constitucionales. Esto se debe principalmente a la desconfianza de la gente en los tribunales. Se ha demostrado que la capacidad de la sociedad para superar el fenómeno de la corrupción en el sector público tiene que ver en gran medida con la voluntad de transparencia y apertura de toda la información, la madurez anticorrupción tanto de la sociedad civil como del gobierno. Se establece que la lucha contra los delitos de corrupción penal, sobre la base de las herramientas y medios de digitalización de los servicios públicos, promueve la confianza pública en el gobierno, se convierte en la base para la formación de la cultura de lucha contra la corrupción.
\end{abstract}

Palabras claves: Digitalización; Servicios públicos; Delitos de corrupción penal; Reformas; Herramientas digitales.

Clasificación JEL: K14, M15, O38

Recibido: 09 de abril de 2021

Aceptado: 12 de junio de 2021 


\section{Introduction}

\section{Relevance of the topic and problem statement}

In recent years, the world has been implementing strategic information systems, digitization initiatives to improve services and combat corruption (Kim, et al., 2009; Neupane, et al., 2012; United Nations, 2016). Political changes in 2019 led to the creation of a "window of opportunity" for Ukraine to implement anti-corruption policy. However, the credit of trust in the government decreases over time if the people do not feel the real results of overcoming the phenomenon of corruption.

Society actively criticizes judges for their lack of independence, impartiality, transparency, accountability, and corruption. Today's demand in Ukraine is to restore public confidence in the judiciary. The current problem is political corruption at the highest level - $73.2 \%$ of the population of Ukraine believe so. Domestic corruption, which respondents face in everyday life, is considered a less serious problem (53.3\%). Corruption in the business environment is considered to be a more serious problem ( $72.4 \%$ of respondents). Also, according to respondents, ordinary people $(72.7 \%)$, the media (47.3\%), and non-governmental organizations (41.9\%) want to fight corruption the most. The most have convinced that corruption in Ukrainian society has widespread. Thus, $65.5 \%$ of respondents believe that corruption is very common, $21.2 \%$ - quite common, $9.2 \%$ - not very common, and only $1.1 \%$ believe that there is no corruption in Ukraine at all.

Such research results (surveys) are evidence of distrust in state institutions in the field of combating corruption, which has increased compared to 2017 in recent years.

Moreover, the most corrupt spheres of life, according to respondents, are the judiciary (corruption is very common here $-62.2 \%$ of respondents), receiving medical services ( $55.0 \%$ called it very corrupt), the prosecutor's office (54.3\%). However, according to the respondents, the level of corruption in everyday life has slightly decreased compared to previous years. Ukraine faced serious challenges, accompanied by a number of reforms, including reform of the legal system. Currently, one of the largest reforms is the reform of the judiciary. First of all, this is due to people's distrust of the court. Society actively criticizes judges for their lack of independence, impartiality, transparency, accountability, and corruption. Today is demand in Ukraine is to restore public confidence in the judiciary. The problem is the unsystematic anti-corruption policy in Ukraine, its local and fragmentary nature. And although now enoughhigh level of access of citizens to information, including in the form of open data, relevant information is lacking in some particularly important areas. Thus, according to the Open Data Barometer (Country detail) rating, Ukraine received rather low indicators in terms of the availability of cartographic data, data on land ownership, data on the work of the health care sector and the environment. A similar situation has recorded in the Global Open Data Index (Place overview).

In Ukraine, the Unified State Web Portal of Open Data has been created, but the informativeness of the portal does not meet the requirements for the relevance of information. Thus, the phenomenon of corruption in the public administration sector can not be overcome. The relationship between digitalisation and state corruption remains unresolved, as well as what remains to be done to ensure that information systems help curb corruption.

An active search is underway to answer the question of the strategic application of digitalization in state reforms and the fight against corruption.

The purpose of the study is an analysis and assessment of the role of a digitalization of public services in combating criminal corruption offenses.

This study highlights the following issues:

-identify the features and main aspects of modern knowledge about digitalization and corruption and the nature of the links between them;

-identify key factors that minimize the impact of modern knowledge and digital technologies on corruption in the public sector, trace the nature of the links between them;

-identify key areas for further work in the fight against corruption, given the strategic importance of digitalization and its interaction with corruption. 
Research hypotheses:

$\mathrm{H}$ 1. The ability of society to overcome the phenomenon of corruption in the public sector has associated, to a greater extent, with a willingness to transparency and openness of all information, anti-corruption maturity of both civil society and government.

H 2. Counteraction to criminal corruption offenses, based on the tools and means of digitalization of public services, promotes public confidence in the government, becomes the basis for the formation of anti-corruption culture.

\section{Literary review}

Corruption is one of the three biggest problems in Ukraine ("Join in!"). After the high cost of living and low wages, hostilities in Donetsk and Luhansk regions. Moreover, it is political corruption at the highest level that poses the greatest threat: this was stated by $92.5 \%$ of citizens, some of whom (26\%) called the elimination of the institution of parliamentary immunity the main step in overcoming corruption.

Among researchers, there are different approaches to understanding and defining the concept of corruption:

- in essence - it is a hidden phenomenon, so its measurement - a difficult task that requires indirect indicators (Shukhova, 2017);

- the level of power of attorney, which has established by the model of behavior and perception of corruption by society (Karv, 2015);

- abuse of public power or official position for private / personal gain (Csáki \& Gelléri, 2005).

The latter approach is the dominant definition, but there are currently no conceptual approaches to explaining the true nature of this phenomenon.

For example, it has been shown that in countries where a nepotism is common, organizational affinities (a family and a clans) appear to be more prominent in corruption. However, there are phenomena of agreements that have led to the formation of a new class - the oligarchs, which significantly increases the incentives for corruption in government (Joseph, 1987; 1996). In this case, corruption in the public sector is not a guarantee of civil servants, but is actively and usefully absorbed by private citizens, who stimulate civil servants (Ufere \& Carlson, 2012).

The Kossow \& Kukutcha (2017) view corruption as a problem of collective action related to the control of corruption through the empowerment of citizens and the support of civil society. Addo (2018) considers state corruption an opportunistic crime, with the author explaining the role of technology in exposing and preventing corruption.

The Andersen (2009) the first, who assessed the level of corruption control (CCI) according to the World Bank methodology. According to its analysis, the development of e-government has a corresponding impact on the control of corruption, which has expressed by moving the country to a higher world rating (the higher the place, the better).

The most researchers conclude that digitalization will improve business processes, ensure transparency and monitoring, and curb corrupt behavior. The authors distinguish the following types of digital technologies: information, computing, communication and connection technologies (Bharadwaj, et al, 2013; Vial, 2019).

The digital technologies were used in public administrations with direct or indirect expectations of the impact on corruption. The use of digitalization as the main tool in the fight against corruption is mainly due to the fact that expectations from digital technologies should be conceptualized by anticorruption strategy, given the causes and possibilities of corruption (Saddler, 2007; Syed \& Bandara, 2019).

Access to data, as the main resource of the future, requires the development of an appropriate digital infrastructure capable of ensuring data sovereignty and, at the same time, sharing data on a broader and more secure basis (in The Straits Times, 2019). Digital transformation of society has 
connected with data as a key element of the fourth industrial revolution (Schwab, 2018). Recent trends have already led to cheaper and more accessible storage and processing facilities, increased availability of data via the Internet, social networks and the Internet of Things (IOT), and improved data analytics through the "deep learning" revolution. Modern artificial intelligence (Al) extracts values from data, there by increasing data availability, leading to more accurate Al models. This, in turn, increases opportunities and benefits for government, society and business (EPSC, 2019).

For the OECD countries, the impact of e-government services on corruption is insignificant (Lee, 2017). Instead, this effect has quite pronounced for developing countries.

Studies of corruption factors, on the example of Estonia (Karv, 2015), have shown a direct relationship between the level of corruption and factors such as transparency, accountability, the disappearance of intermediary officials and the reduction of the gap between officials and citizens in the country. It has established that the most significant is the disappearance of intermediary officials. The active use of electronic administrative services has reduced users' direct contact with officials, which has taken them out of the game.

Studies of the results of specific projects in some countries (Csáki \& Gelléri, 2005; Pathak \& Prasad, 2006; Iqbal \& Seo, 2008) have shown a fairly high efficiency of e-government in the fight against corruption. There are other opinions, as the expected effect may not be (Heeks, 1999; Bhatnagar et al., 2007), which confirms that corruption is a complex phenomenon, the result of a number of components, so measures to combat it should be systemic.

Factors that may limit the effectiveness of e-government and the implementation of digitalization of public services (Ojha et al., 2008):

- the ability to adapt services to online - not all services can be provided without personal contact;

- the legal and administrative aspects of providing services in electronic format;

- the presence in the chain of the process of providing services to officials who have the right to make decisions;

- the shortcomings in the functioning of e-government infrastructure, etc.

\section{Methodology}

The figure 1 summarizes the overall design of the study, describing its logic underlying the three main areas of work to address the specific purpose of the study.

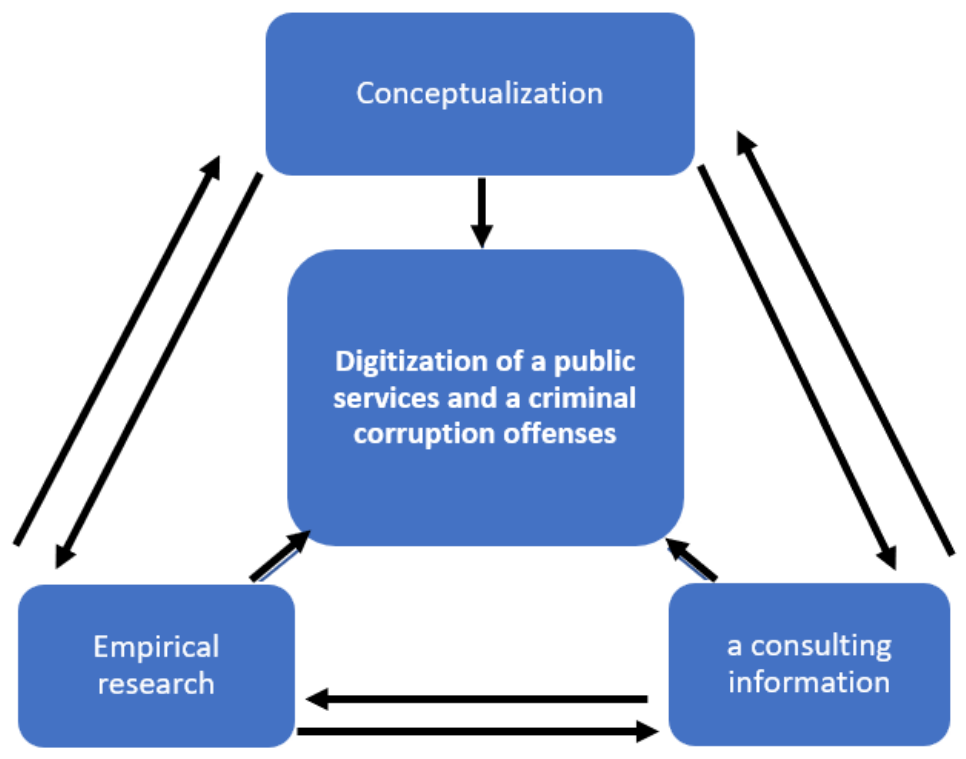

Figure 1. Research design

The empirical research includes the collection and systematization of: 
- a secondary evidence through a review of the literature and relevant policy documents on the subject of the study - the digitization of public services as tools and mechanisms to combat criminal corruption offenses;

- a primary evidence through fieldwork and experimental case studies.

Conceptualization includes:

- a conceptual-analytical and theoretical developments - in order to open the way for a deeper analysis of the consequences of the influence of digital government and digitalization of public services in combating criminal corruption offenses;

- a development of framework conditions within which evidence from case studies / experiments can be displayed.

An advisory information concerns:

- an involvement of experts and stakeholders;

- a conducting peer reviews and discussions in seminars and through the DigiGov online community, in order to improve the effectiveness of countering criminal corruption offenses, using the tacit knowledge and ideas of key experts and stakeholders, and to validate research findings and their relevance to practice and policy.

The approach of mixed methods of triangulation has used for carrying out research. Mixed research methods that combine and triangulate different methods and sources (both primary and secondary) are particularly relevant for applied policy research on policy interventions in complex ecosystems, contributing to the emergence of new categories, theories and hypotheses (instead of relying on a priori concepts and ideas) to describe the interventions in their real context from the researcher's point of view.

To use of mixed methods was considered the best approach to solve the problems of this study:

- to study new technological possibilities of digitalization of public services from a different disciplinary perspectives (institutional, cultural, behavioral);

- to consider the views of the involved stakeholders on the researched problem, to experiment with them;

- to involve both stakeholders and experts in interactive discussion and verification activities on the possibility of forming a consensus to solve the problem under study;

- development of recommendations and future scenarios for the digital transformation of the government and the formation of conditions and opportunities for the positive impact of digitalization of public services in combating criminal corruption offenses.

\section{Evaluation and analysis of results}

\subsection{Analytical assessment corruption and its perception in Ukraine}

The Ukraine scored 30 points out of 100 according to the Corruption Perceptions Index 2019 (CPI), have reported by Transparency International. The corruption index in Ukraine averaged 25.19 points from 1998 to 2019, reaching a peak of 32 points in 2018 and a record low of 15 points in 2000 (Fig. 2).

According to the Corruption Perceptions Index, Ukraine in 2018 ranks 120th (32 points) among 180 countries. The indicator has slightly improved (2017 - 30 points, 130th place; 2016 - 29 points, 131st place).

The improvement of the situation has caused by the introduction of the procedure of automatic reimbursement of value added tax, expansion of the scope of ProZorro and ProZorro Sales systems and the activities of the business ombudsman institute. 


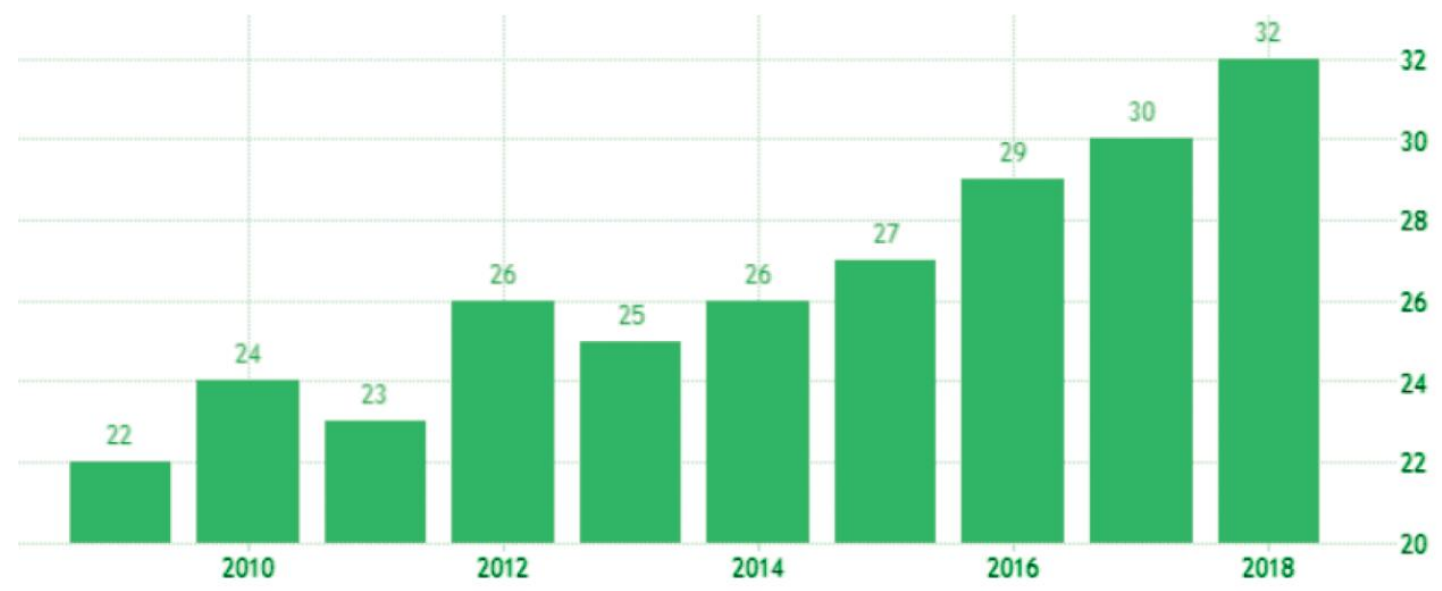

Figure 2. Dynamics of the corruption perception index in Ukraine

(Ukraine Corruption Index)

According to a sociological study (How Ukraine Fights Corruption):

- 83\% of respondents consider the fight against corruption in Ukraine unsuccessful (in $2017-80 \%$ ), $50 \%$ - a complete failure (in 2017 - 46\%), 9\% - see success in the fight against corruption (in 2017 - 15\%) ), and only $1 \%$ - assess this struggle as completely successful (in $2017-2.5 \%$ );

- $48 \%$ of respondents do not see any instance that would actively fight corruption in Ukraine (in $2017-43 \%)$;

- $26 \%$ of respondents named among active activists against corruption the media and journalists (in 2017 - 26\%), 18\% -the anti-corruption public organizations (in $2017-21 \%$ ), 11\% - the NABU (in 2017 $24 \%$ ), $10.5 \%$ - the population itself (in 2017 - 12\%), 10\% - an individual politicians, public figures, 6\% a Western countries;

- only a small percentage of the population among active fighters against corruption was indicated by those state institutions that have to fight corruption. $5 \%$ of respondents named such institutions as Security Service of Ukraine and specialized anti-corruption prosecutor's office, $4 \%$ - the National Agency for Corruption, the GPU, the President of Ukraine, 3\% - the NPU, 2\% - the CMU, a ministries and other central executive bodies, $2 \%$ - the VRU, $1.5 \%$ - a local governments, $1 \%$ - a courts;

- $15 \%$ of respondents positively assessed the effectiveness of the fight against corruption the NABU, $13 \%$ - the Security Service of Ukraine, 10\% - the NPU, $9 \%$ - the GPU, $6 \%$ - a specialized anti-corruption prosecutor's office and the National Agency for Corruption, $4 \%$ - a courts;

- $79 \%$ of respondents received a negative assessment of the effectiveness of the fight against corruption from the courts, $75 \%$ from the GPU, and $74 \%$ from the NPU;

- a significant part of citizens could not give a definite assessment of the activities of these bodies (from $16 \%$ for the NPU, to $34 \%$ for the National Agency for Corruption).

The problem of corruption is a key factor in holding back economic reforms in the country. According to a survey of foreign investors, the main obstacles to foreign investment in Ukraine are (on a 10-point scale):

1) widespread corruption - 8.3;

2) distrust of the judicial system - 8.2;

3) monopolization of markets and seizure of power by oligarchs - 6.5 .

Thus, the problem of corruption in the country has perceived by various stakeholders as a key political problem in Ukraine, possible progress in overcoming it has not observed. In particular, according to a sociological survey, as of the beginning of 2020, Ukrainians have not felt significant and effective steps by the authorities to combat corruption:

- 71\% of respondents stated that there were no changes ("No changes at all" and "Almost no changes") in the promotion of anti-corruption reform; 
- $22 \%$ of respondents noticed some reform steps of the government, and this figure decreased by 4\% compared to 2019 ("Active change" - 4\%, "Fairly slow change" - 21\%).

\subsection{Analysis of legal reform: anti-corruption authorities in Ukraine}

An extremely important step in the implementation of legal reform is the creation of anticorruption bodies. Among a number of institutions that play the most important role in combating corruption in the country, respondents noted:

- $\quad$ an anti-corruption bodies ( $38 \%$ of respondents);

- $\quad$ the President of Ukraine / Office of the President of Ukraine (32\%);

- a police and a prosecutor's office (24\%).

According to the respondents, currently the role of a citizens in this process is more important than the courts ( $19 \%$ vs. $15 \%)$.

The newly elected President of Ukraine is one of the leaders of Ukrainians' hopes in conducting anti-corruption measures. In 2019, 29\% of Ukrainians acknowledged the readiness of the newly elected President of Ukraine to fight corruption (against 4\% for President Mr. Poroshenko in May 2018).

At the same time, the level of trust in the authorities (including anti-corruption bodies, which, according to respondents, are leaders in the importance of the role in combating corruption) at the end of 2019 remains low.

Thus, during 2014-2018, a number of anti-corruption bodies were established, namely: the National Agency for the Prevention of Corruption (NAPC); the National Anti-Corruption Bureau of Ukraine (NABU); the Specialized Anti-Corruption Prosecutor's Office (SAP); the Asset Search and Asset Management Agency (ASMA); the State Bureau of Investigation (SBI); the Supreme Anti-Corruption Court (SAC). A types and bases of tasks of anti-corruption bodies are shown in Fig. 3.

\section{Anti-corruption bodies of Ukraine}

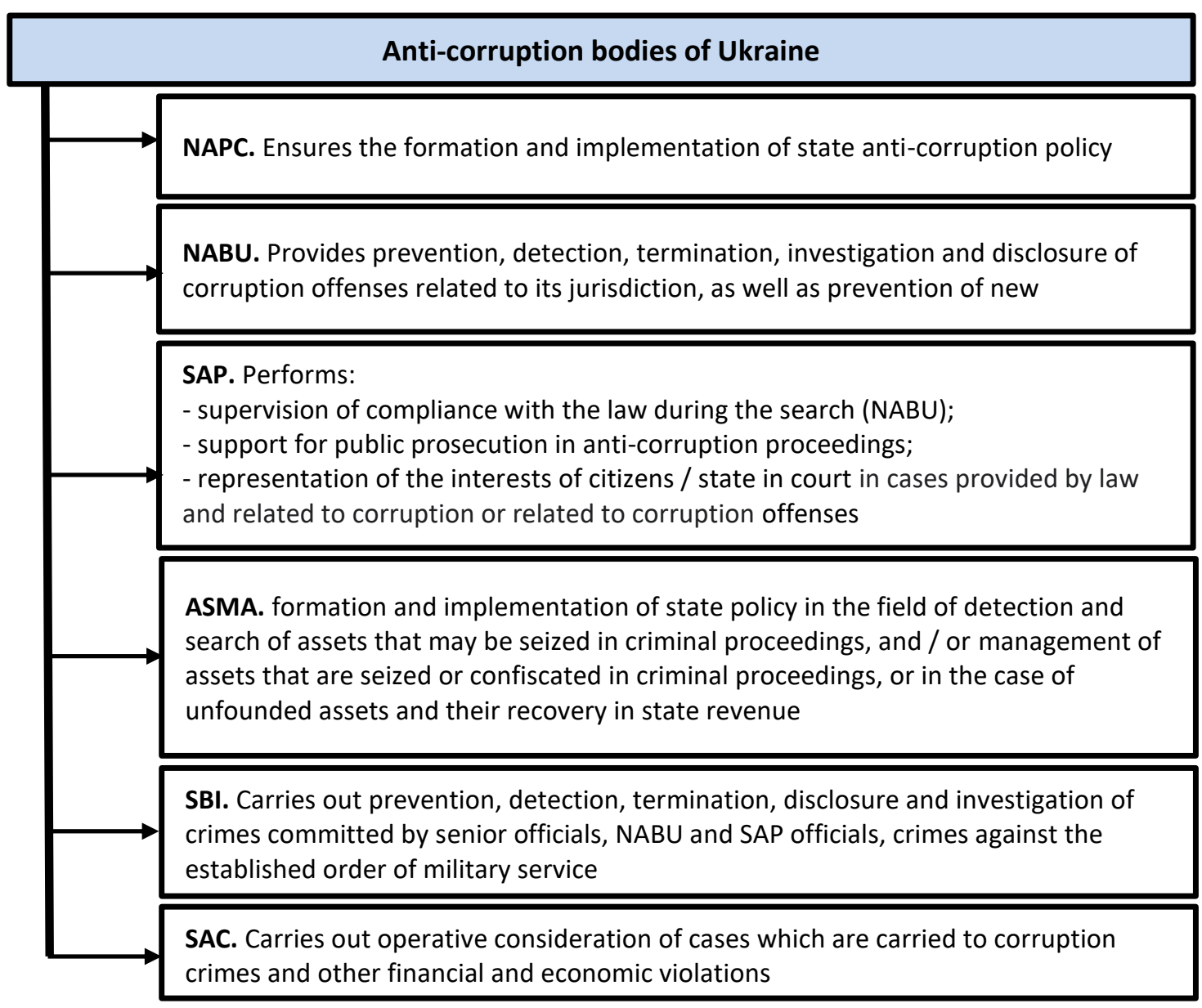

Figure 3. Anti-corruption bodies of Ukraine and their functions 
The indicators of anti-corruption bodies are as follows: the NABU - 29\%, the NAPC - $21 \%$. From July 2018 to January 2019, the share of respondents who consider the important role of the President in combating corruption increased by $4 \%$ (from $28 \%$ to $32 \%$ ), and an anti-corruption bodies - by $6 \%$ (from $32 \%$ to $38 \%)$.

The most of citizens do not trust the judiciary (the balance of trust-distrust -62\%), the local courts $(-53 \%)$, the prosecutor's office $(-50 \%)$, the higher anti-corruption court $(-42 \%)$, the NAPC $(-40 \%)$, the SAP $(-40 \%))$, the NABU (-36\%), the Constitutional Court of Ukraine $(-36 \%)$.

Only the President of Ukraine has a positive balance of confidence (+ 32\%).

\subsection{Characteristics of the main changes that have taken place in the field of formation and implementation of state anti-corruption policy in Ukraine}

In 2019, there will be intensified efforts in the field of formation and implementation of anticorruption policy in Ukraine. Compared to 2018, when the Law of Ukraine "On the Supreme AntiCorruption Court" was adopted, in 2019 there were much more significant events for anti-corruption policy.

In the first half of 2019, the Constitutional Court of Ukraine (CCU) ruled on the inconsistency of Art 368-2 of the Criminal Code (CC) of Ukraine, which established criminal liability for illicit enrichment, the provisions of the Constitution of Ukraine. As a result of this decision, 65 criminal proceedings concerning possible illicit enrichment, the pre-trial investigation of which was carried out by NABU detectives, were closed.

The decision of the Second Senate of the CCU of June 5, 2019 declared unconstitutional the provisions of the Law of Ukraine "On the National Anti-Corruption Bureau of Ukraine", according to which NABU had the right to file lawsuits to invalidate agreements in the manner prescribed by law. This decision was also criticized by members of the public.

At the same time, on June 6, 2019, the CCU quite rightly declared unconstitutional the provisions of the Law of Ukraine "On Prevention of Corruption", according to which representatives of public associations engaged in anti-corruption activities were obliged to submit property declarations previously introduced to a wide range of public servants. This decision was positively assessed by both civil society and Ukraine's international partners.

In the first half of 2019, the process of establishing the Supreme Anti-Corruption Court took place.

In June 2019, the President of Ukraine changed the composition of the National Council for AntiCorruption Policy, at a meeting of which 5 key priorities were proposed, which should be achieved by the end of the year:

1) revision of anti-corruption legislation;

2) changes to the criminal procedural legislation;

3) strengthening the protection of whistleblowers;

4) adoption of a new anti-corruption strategy;

5) fulfillment of Ukraine's international obligations.

However, none of the tasks were fully completed by the end of the year.

The Verkhovna Rada of Ukraine adopted the Law of Ukraine "On Amendments to the Law of Ukraine" on the Supreme Anti-Corruption Court "(concerning the commencement of court proceedings)". This bill was positively assessed and supported by experts and public organizations. However, the decision is temporary and a more sustainable and comprehensive solution has needed to solve the problem in the long run.

The Verkhovna Rada of Ukraine adopted Law 140-IX, aimed at improving institutional mechanisms for preventing corruption. The main legislative changes concerned the introduction of new approaches in the activities of the National Agency. Among the main provisions of this law are that:

- the collegial model of the NAPC management has changed to a single one; 
- the approach to the formation of the commission for competitive selection of the NAPC Chairman has changed, which now includes 6 people, 3 of whom have determined by donors and have a decisive influence in selecting the winner of the competition;

- as a result of the entry into force of this law, an internal control unit, a corruption prevention unit were established in the NAPC, as well as a integrity check on the NAPC employees was introduced;

- all inspections have now distributed among the authorized persons of the NAPC automatically;

- it strengthened the role of the Public Council at the NAPC and changed the approaches to its formation;

- the level of accountability of the NAPC was increased due to the introduction of an external independent evaluation of the effectiveness of the NAPC, which will be conducted every two years by a commission consisting of three persons nominated by donors;

- the NAPC received the right of direct automated access to all necessary state registers and databases, as well as the right to use foreign registers.

Some other norms of the Law of Ukraine "On prevention of corruption ", in particular:

- the list of information that must be indicated in the property declarations of public servants has clarified, and the obligation to indicate additional information has added, for example, information on bank accounts, affiliation of the declaring subject to national public figures, etc .;

- the list of close persons was clarified, the approach to determining family members was changed, as well as the issue of declaring assets in use and indicating in the declaration the persons with whom the declaring subject lived together in the reporting period was settled;

- the obligation to report significant changes in property status now applies only to officials holding a responsible or special position or positions with a high and high risk of corruption;

- the subjects covered by the Law of Ukraine "On Prevention of Corruption" included persons holding patronage services.

Some changes were also made to the Code of Ukraine on Administrative Offenses (CAO of Ukraine). The adoption was generally welcomed by the vast majority of stakeholders.

The Verkhovna Rada of Ukraine adopted a package of laws:

- a Law of Ukraine "On Amendments to Certain Legislative Acts of Ukraine Concerning the Improvement of Certain Provisions of Criminal Procedure Legislation". The draft law clarified some other provisions of the Criminal Procedure Code (CPC) of Ukraine and the Law of Ukraine "On the National Anti-Corruption Bureau of Ukraine";

- a law aimed at strengthening the protection of whistleblowers, which introduced a new definition of whistleblower; established requirements for the creation of various channels for whistleblower messages; identified safeguards for whistleblowers and their rights; gave whistleblowers the right to receive remuneration; defined the powers of the National Agency, authorized units (persons) for the prevention and detection of corruption, other entities to protect whistleblowers and review their reports, etc .;

- the Bill 31 1031, which restored criminal liability for illicit enrichment, as well as the introduction of a new procedure for Ukraine for the civil confiscation of unjustified assets of public servants. To this end, additional powers have been granted to certain specially authorized entities in the field of anticorruption.

Special mention should be made of the presidential initiative to amend the Constitution of Ukraine to authorize the President of Ukraine to establish the NABU and appoint its Director in the manner prescribed by law (Bill № 1014).

On September 5, 2019, the Supreme Anti-Corruption Court began its work, and the formation of the court staff began.

In December 2019, the Law of Ukraine "On Amendments to Certain Laws of Ukraine on Prevention and Counteraction to Political Corruption" was adopted, which clarified the provisions on the 
procedure for making contributions in favor of political parties and restrictions on their implementation; the provisions on the financial statements of political parties have been revised and an electronic register for such reports has been introduced.

Another important Law of Ukraine "On Amendments to Certain Legislative Acts of Ukraine" was adopted in order to bring it into line with the Law of Ukraine "On Amendments to Article 80 of the Constitution of Ukraine Concerning the Inviolability of People's Deputies of Ukraine". In fact, it determines the peculiarities of the pre-trial investigation of people's deputies, which has a significant impact on the achievement of the objectives of criminal proceedings against them. Unfortunately, the provisions of this Law are assessed as inconsistent with the general principles of criminal proceedings and set unreasonable requirements and restrictions.

\subsection{Additional opportunities for digitalization of the public services in combating criminal corruption offenses}

In 2019, the Government's Action Program proclaimed the digitization of all spheres of public administration and provision of services, thanks to which it was possible to expand the scope of work of state and local governments to disclose information, including in the form of open data publication of registers and continuation of e-government policy.

In 2020, a report on the initial results and anti-corruption effects of the introduction of digitalization was presented public services. The total potential effect of digitalization of the 17 most common services in 7 areas has projected to reach UAH 1.3 billion annually (Report).

An independent experts conducted a study on the evaluation of e-services in the USAID / UK aid project "Transparency and Accountability in Public Administration and Services / TAPAS" and the SwissUkrainian e-Government for the Government Accountability and Community Participation (EGAP) program. Ukraine in such areas (Report):

- a registration, amendments and termination of registration of a natural person-entrepreneur (the Ministry of Justice);

- an appointment of childbirth assistance (the Ministry of Social Policy);

- a providing a certificate of no criminal record (the Ministry of Internal Affairs of Ukraine);

- a declaration of compliance with fire safety requirements (the State Service of Ukraine for Emergencies);

- an issuance and extension of a license for road transport services for passengers and goods, notification of changes in the carrier's data (the State Service of Ukraine for Transport Safety (the Ukrtransbezpeka));

- an obtaining and revoking a permit for special water use (the State Agency of Water Resources of Ukraine);

- a notification of the start of preparatory and start of construction works, declaration of readiness of the facility for operation (the State Architectural and Construction Inspectorate of Ukraine).

According to the results of the analysis, it has established that the savings on all surveyed services, as a consequence of obtaining them online, is:

- a potential savings of 495 million UAH per year;

- a real savings of 36.7 million UAH per year.

The poll showed that $78 \%$ of respondents believe that corruption has decreased, of which $52 \%$ has decreased significantly.

Savings on all researched services, as a consequence of the anti-corruption effect, are:

- a potential savings of 841 million UAH per year;

- a real savings of 32 million UAH per year. 
In this case, the anti-corruption effect has considered to be a reduction in the money that would potentially be paid by citizens and businesses in the form of bribes or hidden payments in favor of intermediaries. That is, the economic effect is to avoid possible losses that have not suffered by businesses or citizens in the process of receiving services electronically.

It has believed that:

- the 840 million UAH per year is a potential anti-corruption effect from the introduction of electronic services, ie if all services are online;

- the 490 million UAH are funds that will be saved by businesses and citizens as a result of digitalization public services.

Currently, a system of an organizational support is being formed in Ukraine digitization of public services.Thus, in all ministries, deputy ministers have been appointed to be responsible for the digital transformation of the relevant sector. The Ministry of Digital Transformation is working to create a single source of electronic services.

In addition, the Ministry of Digital Transformation, together with the national standard "Action" implements a single centralized approach with a mobile application and a portal of electronic services from a single source, providing on the basis of these two tools a single technical support for all services. Already implemented:

- a system of effective chatbots that respond quickly to both typical and atypical questions;

- there is a single support service, which according to the same rules and standards quite effectively advises all users on the provision of services on the portal "Action".

Some services, such as a transport licenses or a water permits, still exist on some resources, and there is a clear plan to migrate these services with new quality and reengineering to the Action portal.

Thus, the introduction of electronic services in Ukraine has not only economic but also an anticorruption effect. Moreover, for Ukraine the anti-corruption effect is the most significant, because certain anti-corruption risks have eliminated, a contact between the official and the subject of the appeal is impossible: the citizen and business.

The Law of Ukraine "On Prevention of Corruption" sets requirements for transparency and access to information of a public interest as defined by the Law of Ukraine "On Access to Public Information".

According to the Global Rating of the Right to Information (RRI), the Ukraine ranked 29th out of 128 countries in 2019 in terms of the quality of legislation on the right to access information, gaining 108 points out of 150 possible. That is, a national legislation defines a mechanism to ensure that a citizens exercise their right to information and access procedures and a methods of obtaining information.

According to the Global Open Data Index, Ukraine ranks 31st out of 94 countries, receiving a data openness rating of $48 \%$ out of a maximum of $100 \%$.

The Ukraine has approved an Action Plan for the Implementation of the Principles of the International Open Data Charter, which provides for about 30 measures to ensure the realization of a citizens' right to access an information, increase openness and transparency of a public authorities and stimulate an innovation.

At the end of 2018, the Cabinet of Ministers of Ukraine approved an Action Plan for the implementation of the Open Government Partnership Initiative. The public authorities keep records and register requests for public information, form an automated database. An information managers ensure the publication and updating of information on official websites regarding their activities, their organizational structure, a functions, a powers, the main tasks, a regulations, a draft decisions, etc.

In December 2015, with the adoption of the Law of Ukraine "On Public Procurement", the full functioning of the procurement system through an electronic auctions was introduced in Ukraine. However, there are still many problems in the functioning of the public procurement system.

In October 2019, the Transparency International Ukraine published a report "Beyond ProZorro: Does Ukrainian Business Trust Public Procurement?, According to which $80 \%$ of procurement participants have satisfied with the interaction with ProZorro sites. 
At the same time, $24 \%$ of respondents stated that they had direct contact with a corruption when working with the ProZorro system, and another $19 \%$ - that their acquaintances had encountered a corruption when working with this system. On the other hand, $41 \%$ of respondents said that they had not encountered a corruption in ProZorro (this figure exceeds the similar figure that took a place before the introduction of the electronic online system by $9 \%$ ).

Among the problems that the businesses most often face in public procurement were identified:

- a discriminatory requirements in the tender documentation (69.9\%);

- a requirements of optional documents (68.1\%);

- an unjustified rejection of the proposal (55.8\%).

On September 19, 2019, the Verkhovna Rada of Ukraine adopted the Law of Ukraine "On Amendments to the Law of Ukraine" On Public Procurement "and some other legislative acts of Ukraine on improving public procurement."

Guidelines on ethical behavior of customers during public procurement and on ethical behavior of a participants (a potential participants) during a participation in public procurement have been developed.

One of the main controlling bodies in the field of public procurement during 2019 was the State Audit Office of Ukraine (from December 11, 2019 its successor became Financial control office), which since the beginning of 2018 has received the authority to conduct online monitoring of the public procurement at all stages of procurement: from the announcement to the conclusion of the contract, as well as during its direct implementation.

During 2019, the State Audit Office of Ukraine and its interregional territorial bodies monitored more than 8.7 thousand procurements with a total value of 82.5 billion UAH. Monitoring of the 8.1 thousand procurements ( $93 \%$ covered by the control) revealed violations committed by customers during procurement, totaling 71.8 billion UAH.

Most violations were committed by customers due to non-compliance with the procedure for compiling forms of documents and disclosure of information on procurement (28.9\%), consideration by the customer of tender proposals (26.9\%), preparation of the tender documents $(23.7 \%)$ and misuse of the negotiated procedure (4\%).

These control measures were mostly (61.8\%) carried out on the basis of signs of violations of the legislation in the field of public procurement identified by the state financial control body. In addition, the measures taken on such grounds are the most effective, as $98 \%$ confirmed the existence of violations during the procurement of customers.

According to the appeals of public associations, decisions on the start of procurement monitoring were made in $14.3 \%$ of cases, on the basis of automatic risk indicators $-11.1 \%$, appeals of public authorities and local governments $-5.8 \%$, reports in the media $-0.3 \%$, in the presence of several of these grounds $-6.7 \%$. According to the results of procurement monitoring, due to the proper response of customers, it was possible to prevent the use of a state and a municipal resources under procurement procedures conducted in violation of the law, totaling almost 16.8 billion UAH, of which canceled 2.6 thousand purchases with a total expected value of 14.6 billion UAH and 0.9 thousand contracts for a total amount of 2.2 billion UAH were terminated.

During the last year, within the framework of the implementation of the results of procurement monitoring, as well as procurement inspections conducted after such monitoring, 539 protocols on administrative offenses under Art 164-14 of the Administrative Code of Ukraine.

The 43 persons were brought to administrative responsibility, on whom the courts imposed administrative fines (fines) in the total amount of 523.6 thousand $\mathrm{UAH}$.

The current anti-corruption legislation provides for two types of anti-corruption programs:

1) an anti-corruption programs of public authorities, local governments and other legal entities under public law, defined in Art 19 of the Law "On Prevention of Corruption";

2) an anti-corruption programs of legal entities (mostly private law), defined by Art 62 of the Law 
"On Prevention of Corruption".

An anti-corruption programs should be based on the results of the corruption risk assessment. In the 106 state bodies and the local self-government bodies there are commissions for corruption risk assessment, in the 25 such assessments were conducted by authorized subdivisions (persons) for prevention and detection of corruption.

It is worth noting that the 22 state bodies identified external corruption risks based on the results of corruption risk assessments. Most of them were unregulated certain procedures or imperfections of the normative legal acts adopted by the Verkhovna Rada of Ukraine, the Cabinet of Ministers of Ukraine or central executive bodies. The NAPC did not independently conduct corruption risk assessments in certain areas or other government agencies.

In 2019, the NAPC provided 415 clarifications, consultations, explanations and answers for those who assess corruption risks in the preparation of anti-corruption programs. In addition, during the relevant period, the NAPC representatives conducted training events (trainings, seminars, etc.) on corruption risk assessment and preparation of anti-corruption programs in seven government agencies.

The official website of the National Agency publishes requirements for the preparation of the anticorruption programs, as well as typical shortcomings that ultimately lead to refusals to approve the anti-corruption programs.

The effectiveness of the instrument of anti-corruption programs was analyzed in the report of the Center for Political and the Legal Reforms based on the results of monitoring the NAPC's activities to ensure the assessment of corruption and preparation of the anti-corruption programs in state institutions.

This Report has based on the results of an in-depth analysis of 14 anti-corruption programs, interviews and information on the NAPC activities in this area. In particular, it draws attention to the fact that:

- an issues of corruption risk assessment, proper training and implementation anti-corruption programs are not among the priorities of heads of state institutions;

- the vast majority of state bodies lack sufficiently motivated and qualified employees who could organize a proper assessment of corruption risks and prepare an anti-corruption program based on the results of the assessment;

- the NAPC's efforts to strengthen its capacity to assess corruption risks and prepare anti-corruption programs are insufficient. In particular, this applies to the provision of consultations and the preparation of informational and explanatory materials. Such work is very important for significantly improving the quality of risk assessments and anti-corruption programs developed based on their results;

- the NAPC's institutional capacity to assess corruption risks and prepare anti-corruption programs remains low. The reason is the lack of proper attention to these institutions in previous years by the management and the lack of a strategic vision of development in these aspects;

- aquality of the analysis of anti-corruption programs in their approval by the NAPC was mostly not high, and the regulations approved by the NAPC need further significant improvement;

- a representatives of civil society do not pay much attention to these institutions due to lack of confidence that their application will be effective and will be able to influence the state of corruption risks in a particular institution.

\section{Conclusion}

In this study the main aspects of the introduction of digitalization of public services and their role in combating criminal corruption offenses have considered.

The corruption has assessed on the basis of an analytical study and its perception in Ukraine. The main trends have considered, the main patterns of legal reform, anti-corruption authorities in Ukraine 
have highlighted. The analysis uses the results of a survey to identify problematic aspects of the perception of corruption in Ukraine, the results and feasibility of measures to reform the anticorruption system of Ukraine.

It has proved that the ability of society to overcome the phenomenon of corruption in the public sector was associated, to a greater extent, with the willingness to transparency and openness of all information, anti-corruption maturity of both civil society and government.

It has established that the fight against criminal corruption offenses, based on the tools and means of digitization of public services, contributes to the growth of public confidence in the government, becomes the basis for the formation of anti-corruption culture.

\section{References}

1. "Join in!" Every third Ukrainian is ready to join the organized fight against corruption: Ilko Kucheriv Democratic Initiatives Foundation. URL: https://dif.org.ua/article/kozhna-tretya-ukrainkaetsgotovi-doluchitisya-doorganizovanoi-protidii-koruptsii

2. Addo, A. (2018). Controlling Government Corruption through IT: An Opportunity Theory Perspective. International Conference on Information Systems. San Francisco.

3. Andersen, Thomas Barnebeck (2009). "E-government as an anti-corruption strategy", Information Economics and Policy vol. 21, no. 3, p. 201-210. URL: https://www.sciencedirect.com/science/article/pii/S0167624509000110?via\%3Dihub

4. Babenko, V. (2020). Enterprise Innovation Management in Industry 4.0: Modeling Aspects. Emerging Extended Reality Technologies for Industry 4.0: Early Experiences with Conception, Design, Implementation, Evaluation and Deployment Collective monograph. Ed. by Jolanda G. Tromp et al. A John Wiley \& Sons, Inc., Publication, 1-24

5. Begma, V.M., Lutsik, J.O., Skurinevska, L.V., Tkach, I.M., Trehubenko, S.S., Ulianov, K.Y. (2019) Events identification and risks evaluation in the process of planning of risk-oriented internal audit. Espacios, 40 (38), art. no. 15. URL: http://www.revistaespacios.com/a19v40n38/19403815.html.

6. Bharadwaj, A., El Sawy, O., Pavlou, P., \& Venkatraman, N. (2013). Digital Business Strategy: Toward a Next Generation of Insights. MIS Quarterly, 37(2): 471-482.

7. Bhatnagar, S. C., Rao, T. P., Singh, N., Vaidya, R., \& Mandal, M. (2007). Impact Assessment study of e-government projects in India. Ahmedabad, India: Center for e-Governance, Indian Institute of Management, Ahmedabad. URL: https://www.eldis.org/document/A36818

8. Bondarenko, S., Halachenko, O., Shmorgun, L., Volokhova, I., Khomutenko, A. \& Krainov, V. (2021). The Effectiveness of Network Systems in Providing Project Maturity of Public Management. TEM Journal, 10(1), 358-367.

9. Bondarenko, S., Tkach, I., Drobotov, S., Mysyk, A., Plutytska, K. (2021). National Resilience as a Determinant of National Security of Ukraine. Journal of Optimization in Industrial Engineering, 14(1), 111-117

10.Cho, Yong Hyo, \& Choi, Byung-Dae (2004). E-Government to Combat Corruption: The Case of Seoul Metropolitan Government. International Journal of Public Administration, 27(10), 719-735.

11.Country detail. The Open Data Barometer. URL: https://opendatabarometer.org/countrydetail/?_year=2017\&indicator=ODB\&detail=UKR.

12.Csáki, Csaba, \& Gelléri, Péter (2005). Conditions and benefits of applying decision technological solutions as a tool to curb corruption within the procurement process: The case of Hungary. Journal of Purchasing \& Supply Management, 11(5-6), 252-259.

13.Csáki, Csaba, \& Gelléri, Péter (2005). Conditions and benefits of applying decision technological solutions as a tool to curb corruption within the procurement process: The case of Hungary. Journal of Purchasing \& Supply Management, 11(5-6), 252-259.

14.EPSC. (2019). Rethinking Strategic Autonomy in the Digital Age. URL: https://ec.europa.eu/epsc/sites/epsc/files/epsc_strategic_note_issue30_strategic_autonomy.pdf 15. Heeks, Richard (1999). Information Technology and the Management of Corruption. Development 
in Practice, 9(1/2), 184-189.

16. Holovatyi, M. (2014). Multiculturalism as a means of nations and countries interethnic unity achieving. Economic Annals-XXI, 11-12, 15-18.

17. How Ukraine Fights Corruption - Citizens' Opinion: Ilko Kucheriv Democratic Initiatives Foundation. URL: https://dif.org.ua/article/yak-v-ukraini-boryutsya-z-koruptsieyu-dumka-gromadyan

18.latsyshyn, A. V., Kovach, V. O., Romanenko, Y. O., Deinega, I. I., latsyshyn, A. V., Popov, O. O., . . . LYTVYNOVA, S. H. (2020). Application of augmented reality technologies for preparation of specialists of new technological era. Paper presented at the CEUR Workshop Proceedings, 2547 181-200.

19.Iqbal, M. Sohel, \& Seo, Jin-Wan (2008). E-Governance as an anti-corruption tool: Korean Cases. Journal of Korean Association for Regional Information Society, 11(2), 51-78.

20.Joseph, R. (1987). Democracy and Prebendal Politics in Nigeria: The Rise and Fall of the Second Republic. Cambridge University Press.

21.Joseph, R. (1996). Nigeria: Inside the Dismal Tunnel. Current History.

22.Karv, Jaanus (2015). eGovernment and its ability to reduce corruption. The case of Estonia. Lund University, Department of Political Science, MA Thesis. URL: http://lup.lub.lu.se/luur/download?func=downloadFile\&recordOld=5425282 \&fileOId=5425287

23.Karv, Jaanus (2015). eGovernment and its ability to reduce corruption. The case of Estonia. Lund University, Department of Political Science, MA Thesis. URL: http://lup.lub.lu.se/luur/download?func=downloadFile\&recordOld=5425282\&fileOld=5425287

24.Kim, S., Kim, H., \& Lee, H. (2009). An institutional analysis of an e-government system for anticorruption: The case of OPEN. Government Information Quarterly, 26(1), 42-50.

25.Kossow, N., \& Kukutschka, R. (2017). Civil society and online connectivity: controlling corruption on the net? Crime, Law and Social Change, 1-18.

26.Kuznetsov, A., Smirnov, O., Gorbacheva, L., Babenko, V. (2020). Hiding data in images using a pseudo-random sequence. CEUR Workshop Proceedings, 2608, 646-660.

27.Lee, Eunhee (2017). The impact of eGovernment on Anti-Corruption Control. MARTIN School of Public Policy \& Administration, Graduate Capstone. URL: http://martin.uky.edu/sites/martin.uky.edu/files/Capstone_Projects/Capstones_2017/Lee.pdf

28.Neupane, A., Soar, J., \& Vaidya, K. (2012). The potential of e-procurement technology for reducing corruption. International Journal of Information Technology and Management, 11(4), 273-287.

29.Ojha, Amitabh, Shailendra Palvia And M. P. Gupta (2008). A Model for Impact of E-Government on Corruption: Exploring Theoretical Foundations URL:

https://www.researchgate.net/publication/228369790_A_Model_for_Impact_of_E-

Government_on_Corruption_Exploring_Theoretical_Foundations

30.Pathak, R. D., \& Prasad, R. S. (2006). Role of E-governance in tackling corruption: The Indian Experience. In Raza Ahmad (Ed.), The role of public administration in building a harmonious society, 434-463.

31.Place overview. Global open data index. URL: https://index.okfn.org/place/

32.Report "Anti-corruption and economic potential of e-services". URL: https://www.ukrinform.ua/rubric-presshall/3097916-onlajn-prezentacia-zvitu-antikorupcijnij-taekonomicnij-potencial-eposlug.html

33. Romanenko, Y. O., \& Chaplay, I. V. (2016). Marketing communication system within public administration mechanisms. Actual Problems of Economics, 178(4), 69-78.

34.Saddler, P. F. (2007). Using Digital Hotlines in an Anti-Corruption Campaign. In A.-V. Anttiroiko \& M. Mälkiä (Eds.), Encyclopedia of digital government, 1595-1600.

35.Schwab, K. (2018). Shaping the Fourth Industrial Revolution. Geneva: World Economic Forum.

36.Shukhova, A. (2017). Measurement of Validity of Corruption Indices, Higher School of Economics Research Paper, University of Mannheim. URL:

https://papers.ssrn.com/sol3/papers.cfm?abstract_id=2901307

37.Sudomyr S., Niziaieva V., Lutay L., Prodanova L., Havryliuk O., Sherstyukova K. (2020). Methods And 
Techniques Of Motivation Of Subjects Of Regional Economy For Innovative Improvement. Iternational Journal of Scientific \& Technology Research. 9(3). 1196-11200.

38.Syed, R., \& Bandara, W. (2019). Controlling Corruption in Developing Country Public Sector : A Process Eco s ystems Perspective. International Conference on Information Systems 2019.

39. The Straits Times. (2019). Germany to Unveil European Cloud Gaia-X to Rival Amazon, Alibaba. URL: https://www.straitstimes.com/world/europe/ germany-to-unveil-european-cloud-gaia-x-to-rivalamazon-alibaba.

40.Ufere, N., \& Carlson, B. (2012). Merchants of Corruption: How Entrepreneurs Manufacture and Supply Bribes. World Development, 40(12). 2440-2453.

41.Ukraine Corruption Index. URL: https://tradingeconomics.com/ukraine/corruption-index

42.Vial, G. (2019). Journal of Strategic Information Systems Understanding digital transformation : A review and a research agenda. Journal of Strategic Information Systems, 28(2): 118-144. 